\title{
Governing cooperatives in the context of individual motives
}

\author{
Silvia Sacchetti \\ Department of Sociology and Social Research, University of Trento, Trento, Italy and \\ EURICSE, Trento, Italy, and \\ Ermanno Celeste Tortia \\ Department of Economics and Management, University of Trento, Trento, Italy
}

Governing cooperatives and individual motives

\begin{abstract}
Purpose - This study aims to examine the relationships between the rules that a cooperative membership decides upon and members' motives for action. It considers individual self-interest in relation with motives that are consistent with the values of cooperation.

Design/methodology/approach - This paper comprises two parts. The first is theoretical and discusses cooperative governance's features in the context of individual motives. The second part is empirical and based on survey data from Italian multistakeholder, worker-run social cooperatives. It uses cross-sectional data gathered from 4,134 workers and 310 managers in 310 cooperatives in Italy to provide evidence of rules and individual motives. Regression analysis confirms the existence of a linkage between individual self-interest and motives.

Findings - Rules mainly, but not exclusively, play an enabling function, which implies responding to both nonmonetary and monetary individual motives. With greater articulation within institutions - through the definition of multiple rights for accessing decision-making - the authors expect increases in individual capabilities to match motives with specific organizational rules in pursuit of consistent ends. This is confirmed by the association that the authors found between individual motives and commitment.

Research limitations/implications - The authors' illustration is limited to one specific type of cooperative, the social cooperative, in which prosocial motives are expected to be stronger than in other cooperative forms, although one could say that all cooperative models emphasize procommunity and prosocial aims. Data are cross-sectional and do not allow for the identification of causality, only of statistical relations' strength.

Practical implications - The continuous scrutiny and adaptation of motives and means imply that cooperators communicate and engage in a learning process.

Originality/value - While the institutional spheres that support investor-owned organizations and selfinterested profit-maximizing behavior have been analyzed, a framework that accommodates personal control rights and a richer view of individual motives is lacking. The value added from the paper is to suggest one.
\end{abstract}

Keywords Cooperative firms, Governance, Individual motives, Social aims, Opportunism

Paper type Research paper

\section{Introduction}

Cooperative enterprises can be seen as mutual-benefit organizations created by selforganized cooperators to protect their personal control rights (Ellerman, 2017; Hannachi et al., 2020). The shift is from investor ownership aimed at maximizing profit shares, to member control aimed at pursuing cooperators' welfare, which is understood in monetary and nonmonetary terms and drives cooperators to participate in the cooperative venture. Likewise, nonmonetary motives are expected to be aligned with the values that define the identity of a cooperative organization, which emphasizes self-help, self-responsibility,

C Silvia Sacchetti and Ermanno Celeste Tortia. Published by Emerald Publishing Limited. This article is published under the Creative Commons Attribution (CC BY 4.0) licence. Anyone may reproduce, distribute, translate and create derivative works of this article (for both commercial and non-commercial purposes), subject to full attribution to the original publication and authors. The full terms of this licence may be seen at http://creativecommons.org/licences/by/4.0/legalcode

The authors wish to thank Carlo Borzaga and colleagues at Euricse and acknowledge MIUR/2006 PRIN funding. Usual disclaimers apply.

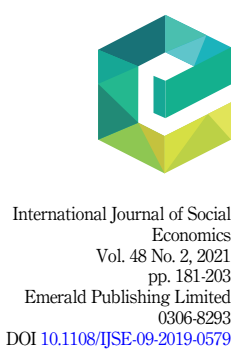


IJSE

48,2 democracy, equality, equity, solidarity, justice, mutual help, social responsibility and caring for others and the community overall (MacPherson, 2013).

Several authors have addressed the challenges in adhering to the specific values that characterize the cooperative firm, for example, with respect to threats to independence from external powers (Hernandez, 2006), managerial slack and poor participation (Spear, 2004), incongruities between democratic processes and the external context (Varman and Chakrabarti, 2004) or between internal democracy on the one hand and oligarchic network governance on the other (Sacchetti and Tortia, 2016). Ultimately, cooperative values and their workings are viewed as an end in view, rather than a stringent feature of this type of organization (Cf. MacPherson, 2013).

The problem of harmonizing the individual and the collective dimensions is far from new. From Smith to Babbage, specialization across society and within the firm has explained the need for market exchange and/or administrative coordination within hierarchies (Kogut and Zander, 1996). In both cases, contrary to conventional approaches, the individual and the collective spheres are not necessarily in conflict. The fact that the cooperative identity is defined by values that are consistent with those of the cooperators implies the existence of bidirectional correspondence between the individual and collective spheres, considering that the organization's values also define what is in the cooperators' interest. Thus, in principle, self-interest also aligns with cooperators' shared interest, which is expressed at an organizational level. Within a cooperative venture, in theory, self-interest is attributed to individual motives consistent with the values that drive the cooperative organization. The implication from our analysis is that we approach cooperation without opposing the individual and collective spheres, but rather ask what type of collective rules are consistent with individual motives that drive cooperators. In the empirical part of the paper, we take worker commitment in terms of willingness to exert increased effort as the criterion variable connecting motives, values, and organizational processes.

Cooperatives are expected to behave in the best interest of their members, that is, cooperators, but in some instances, cooperatives' solutions to market failures, as well as to investor-owned firms' failures, cannot improve members' welfare. Scholars from different scientific approaches repeatedly have emphasized that cooperative governance also may suffer from failures (cf. neoclassical accounts developed by Vanek (1977) or the seminal contributions to institutional theory by Ostrom (1990) and Hansmann (1996). When internal inefficiencies lead to underinvestment (Furubotn and Pejovich, 1970; Vanek, 1970), when cooperative behaviors erode because of free-riding problems (Dawes and Thaler, 1988; Ostrom, 1990) and when access to strategic control is confined within a single stakeholder group because of high governance costs (Hansmann, 1996), cooperatives fail to allocate their resources effectively and efficiently. Failure also can occur when the cooperative strategy mimics that of investor-owned firms. Bager (1994), for example, inquired about transformations of cooperatives into for-profit firms. By the same token, Chaddad and Cook (2004), Fulton and Hueth (2009) and Nilsson (2018) provided an account of how the growth of agricultural cooperatives can engender the spoiling of their cooperative nature. Failures also may occur when negative external effects are produced with other parties. For instance, Sacchetti and Tortia (2016) examplified a case in which large cooperative groups may coordinate with subsidiaries or with their external suppliers without following cooperative principles. In all these cases, effective and efficient allocation breaks down, and the welfare of members, stakeholders and the community at large decays. The issue can be viewed as a coordination problem. When resorting to administrative coordination, the same costs that can cause market failure (e.g. power and information asymmetry) can generate the cooperative failure to act in cooperators and stakeholders' best interest.

Among the critical stances, most notable is the one raising the issue of members' heterogeneity, which would impair the organization's ability to reconcile individual motives and collective objectives (Hansmann, 1988, 1996). From this perspective, heterogeneous 
individual preferences, indeed, can cause divergence between the two dimensions and even contrasts. Such organizational frictions usually are represented by inflated decision-making and/or governance costs relative to more traditional hierarchical solutions (e.g. sole proprietorship in investor-owned companies). From our perspective, heterogeneity undoubtedly can endanger the organization's ability to conjoin the individual and collective spheres, as members' different needs and demands may not be matched properly by collective outcomes, and contrasts are not to be excluded (Iliopoulos and Valentinov, 2017). Organizational failures in reconciling the two dimensions are viewed as potential threats, which are to be tackled by organizational governance, but which need not violate the possibility of achieving superior collective outcomes. Heterogeneity can be screened, filtered and managed upon entrance through proper governance and working rules to favor consistency between individual and collective values (Commons, 1950; Ostrom, 1990). Different positions of individuals or groups of members can be factored in and made compatible through involvement in different processes and bodies. Eventually, heterogeneity is accounted for through an organizational synthesis that mediates between different, or even diverging, motives. The outcomes from such interactive processes cannot be predicted in advance and need not be successful, but respond to the need for open-ended self-organization and production of new rules by the same actors that undergo them, in search of welfare-increasing solutions (Ostrom, 1990; Hannachi et al., 2020).

Consistently with these premises, this study examines the relationships between the rules that a cooperative membership decides upon and members' motives for action. The paper is both theoretical and empirical. The theoretical part is followed by a descriptive presentation of crosssectional worker data from a national survey of Italian social cooperatives, which are worker-run and multistakeholder (as in Travaglini, 2012). Regression analysis is used to examine the linkages between motives for action and commitment, organizational processes and values.

The paper proceeds as follows: Section 2 discusses the state of the art and considers the nature of organizations controlled by cooperators, as well as some of the dilemmas associated with it. Section 3 spells out the theoretical frame, focusing on working rules and governance in cooperatives, as well as some of the relevant differences between investor-owned and cooperative organizations. Section 4 presents the empirical methodology, some descriptive statistics and the regression results. Section 5 discusses the theoretical frame in light of the descriptive evidence and regression results. The relationship between the collective sphere (defined by cooperative rules, aims and personal control rights) and individual motives is generalized.

\section{Literature review and theoretical background}

Cooperatives can be viewed as instances of self-organization of economic activity in terms of collective entrepreneurship, as cooperators engage in democratic action and are in charge of collectively defining their organizations' working rules and production objectives (Reich, 1987; Stewart, 1989; Connell, 1999; Spear, 2012; Vieta et al., 2016; Yan and Yan, 2016; Hannachi et al., 2020) [1] Collective action implies that the cooperator shares broad fundamental values and specific motives to a large extent. Cooperators can be driven by a homogeneous set of motives (e.g. to reflect producers, workers or consumers' interests) or a variety of motives, as in multistakeholder cooperatives (e.g. when membership includes users and workers together). However, multistakeholder governance requires common understanding of transversal values and the common mission. Self-organization allows for different patrons to position themselves in the best possible way within organizational governance. Positioning is not guided exclusively by economic criteria (efficiency), but also by the formative process of the associative pact on which the organization is founded. This pact recognizes the common factors represented by cooperative values, which are related to different needs and expressed in different ways by different groups of patrons, but are based on the unifying principles of solidarity, equity and democracy (Sacchetti and Borzaga, 2020; Hannachi et al., 2020).
Governing cooperatives and individual motives

183 
IJSE

48,2

184

Within this institutional scenario, scholars have identified some open issues, which we summarized further.

\subsection{Income-maximizing choices and loose institutional contexts}

When members are driven by profits rather than by objectives based on cooperative values, management will follow income-maximizing choices (cf. Ward's model of a worker cooperative; Ward, 1958). For example, consider the wave of demutualization, which took place in the United Kingdom particularly after the 1986 Building Societies Act, which increased incentives to demutualize, favoring corporate managers' gains and speculative investors while damaging small mortgagers seeking to finance their family homeownership. It produced a legal framework that favored demutualization without necessarily supporting efficiency or improved market structures (Nilsson et al., 2009; Battilani and Schroter, 2011; Cook et al., 2015; Akinsoyinu, 2017; Shiwakoti et al., 2018). Other frameworks, such as those in Italian and Spanish legislation, place explicit emphasis on cooperatives' nonprofit orientation. In particular, in these countries, cooperatives are required to reinvest at least part of their net surpluses in indivisible reserves that are owned exclusively by the organization and cannot be appropriated by members, not even in the case of demutualization, closure and/or sale of the firm. In this case, the law ties control rights to the individual as a person-member, rather than the individual as owner. In turn, asset ownership mainly rests with the organization, not individual members. Thus, members' rights are defined as personal control rights and cannot be sold as such on the market, as the market for membership rights is excluded by law (Ellerman, 2017). Both categories of institutional constraints make the sale of the firm more difficult and less convenient, dampening the tendency to consider the organization as a saleable object (Putterman, 1988). In this sense, personal control rights reduce the market's role in the exchange of corporate assets, while protecting mutual benefit organizations from the risk of being liquidated for rent-seeking motives.

\subsection{Opportunism and disengagement}

Other types of failure can fall under the broad category of opportunistic behavior, which is (in Williamson's sense) the pursuit of one's own self-interest with guile, including breaking a cooperative pact if advantageous circumstances arise that favor the individual. Of course, this would cause individuals to distrust each other and engage with each other with second thoughts.

In Williamson's (1975) work, organizations are created in the presence of transaction-specific investments carried out by the parties to the contract to reduce transaction costs as related especially to the (actual or potential) insurgence of opportunistic behaviors in the exchanges (Maitland et al., 1985). Among the most notable criticisms levied against Williamson's arguments on opportunism, Ouchi (1980) affirms that the emergence of organizations is explained not by opportunism, but by the need to share the organization's proceeds equitably in the presence of uncertainty and impossibility as to the exact measurement of individual contributions. From our perspective, both opportunism and unequitable choices can be widespread in social systems and can be observed both inside and outside organizations. Correspondingly, opportunism and unfairness can explain the emergence of organizations only when they are conjoined with transaction-specific investments, considering that in this latter case, market exchanges would suffer from increased inefficiency due to inflated transaction costs. Opportunistic and unfair behaviors can, but need not, spread throughout organizations, requiring, in our case, that cooperative governance be devised specifically to guard against their emergence and spread. Counterbalancing reactions directed to restore healthier social interactions within organizational boundaries are expected in such cases.

In the context of cooperative organization, opportunistic behavior, whether from management or members, can take the form of exclusion, managerial slack, value-strategy 
inconsistency, mismanagement or fraud, and it can engender frustration and lack of confidence or trust, leading to the cooperative pact's failure. Some failures are described by Spear (2004), who refers to opportunism in terms of managerial slack in providing or renewing appropriate platforms for member participation and engagement. In addition, managerial slack and members' disengagement are likely to be related in cooperatives, with the former causing the latter. Another instance of opportunism occurs when members freeride on others' good will and cooperation, for example, when members pressure the cooperative to distribute patronage refunds, rather than reinvest them (Von Pischke and Rouse, 2004). Opportunism also takes place when producers use the cooperative as simplified access to the market for their lowest-quality products (Nuhanovic, 2015), or when, in cooperatives with societal aims, worker-members take advantage of information and/or decision-making power asymmetry to disregard disadvantaged users' needs, thereby offering low-quality services (Sacchetti and Borzaga, 2020). In all these cases, opportunism is found at the roots of cooperative failure, signaling cooperative governance's inability to contrast negative organizational outcomes.

\subsection{Conflictual relations}

If cooperative governance's democratic and participatory nature strengthens the organization's adaptive capacity in the face of emerging tensions, then democratic engagement also is dialectic intrinsically and carries the risk of generating excessive governance costs (Hansmann, 1996). These costs likely would be particularly high when conflict is present, leading to a breakdown in coordination. Conflict may accrue among cooperators, for example, between small underinvested and large overinvested producers in farmer cooperatives, small and large creditors in credit cooperatives, member and nonmember workers in worker cooperatives or between workers and users in social cooperatives. In response, scholars have emphasized solutions in a variety of contexts, including within worker cooperatives (Hoffmann, 2005; Hernandez, 2006), farmer-owned producer cooperatives (Staatz, 1987), housing cooperatives (Mojtahed, 2007) and citizen-controlled energy cooperatives (Brummer et al., 2017).

Conflict also may occur between the actors operating at different layers of cooperative governance. For example, Cornforth (2004) and Hernandez (2006) acknowledged formal democratic governance's paradoxes. Analyses recognized the incommensurable tensions that typify internal relationships between groups with different roles, such as the board and membership base, which the board should represent, or between the board and management, in which the board's role is to ensure that choices respect the interests of the membership and cooperative values.

\section{Theoretical framework: cooperative governance and individual motives}

What is the role of rules to prevent cooperative governance failures? Rules' efficacy can be viewed as a matter of degree. In what follows, we explain that rules' efficacy can be related to their consistency with the set of personal control rights recognized by cooperative values and with cooperators' motives. We first discuss rules and the relevant differences between investor-owned and cooperative organizations.

Within institutional theory, rules represent shared and established ways to coordinate resources and address strategic and operational issues. For Kogut and Zander (1996), rules are an important part of a firm's knowledge, as they support coordination and communication because they limit failures from short-term individualistic actions (exemplified by the prisoner's dilemma), which helps overcome the dichotomy between collective action and self-interest. Rules also bear moral significance, that is, when individuals identify with rules and use them to execute practices, strategies and behaviors. By the same token, rules can be viewed as an indicator of what cooperators value. The idea that rules represent a moral code for organizations carries implications
Governing cooperatives and individual motives

185 
IJSE

48,2

186

on what is included in or excluded from organizational governance, practices and incentives. For example, we can appreciate a substantive difference when talking about investor-controlled hierarchies being against cooperator-controlled quasi-hierarchies. While in the first case, rules have been studied closely to limit the incidence of free-riding and opportunism (Williamson, 2000; Valentinov, 2008), in cooperatives, they have been understood as enabling access to strategic control, distributing resources on the basis of patronage and renewing individual motives to cooperate (Tortia et al, 2020). Furthermore, on top of guaranteeing compliance with organizational objectives, rules secure personal rights to be involved equitably and participate in cooperative values, in organizational and decision-making processes and in the distribution of the surplus. On the other hand, the focus on values and involvement does not exclude the former type of considerations, which are likely to be important given that opportunism, when present, can seriously hamper organizational values and the motivation to cooperate.

In the case of investor-owned firms, theory posits that the appropriation of surplus and residual earnings is defined by property rights and follows profit-maximization aims. Individual performance is rewarded when it corresponds with profit-oriented goals. This understanding of incentives views individuals as driven primarily by self-interest or egotistical motives, implying that there is a risk of opportunism associated with individual behavior and a potential conflict between self-interest and the organization's interests. For this reason, organizational economics, particularly principal-agent theory, concluded that rules must be designed to match individuals' assumed egoism and potential to behave opportunistically through monitoring, performance pay, employee stock options and promotions at the organizational level (Jensen and Meckling, 1976). Specifically, monetary rewards have been used widely to incentivize managerial profitability performance and workers' productivity (Milgrom and Roberts, 1992). However, the theory does not consider nonmonetary elements, that is, whether individuals share the organization's values and feel satisfied or treated fairly (Heath, 2009).

Cooperators are expected to self-design rules consistently with both individual benefit and collective welfare in mind. While in cooperatives, incentives for strengthening nonmonetary motives are of primary importance, in profit-oriented firms, the basic incentive problem identified by theory is the reduction of opportunism. In cooperatives particularly, rules are conceptualized as functional to a plurality of motives (nonmonetary and monetary) and aim to benefit all cooperators. Nonmonetary incentives are expected to reinforce cooperators' motives related to engagement and democratic participation in the decision-making process assigned on the basis of personal control rights (cf. Bartlett et al., 1992; Bonin et al., 1993). In cooperatives, monetary rewards also guarantee commitment toward cooperative aims, rather than profit, because they are used to fuel collective action and goals. For instance, rebates or patronage refunds represent a type of monetary incentive whose economic nature is entwined strictly with cooperative organizations because they are shares of net surpluses calculated on the basis of the intensity of the mutualistic relationship between the organization and its members.

However, in practice, the sort of cooperation failures described so far warrant more cautious consideration of the rules and motives featured in cooperatives, especially when there is a considerable distance between the two - a situation that may increase the risk of opportunistic behavior despite cooperative agreements.

\section{Empirical methodology: survey data from socially oriented cooperatives in Italy}

To exemplify the issue of cooperators' motives, we considered cross-sectional data that illustrate motivational variety in Italian social cooperatives. The data presented should be viewed as a way to exemplify our conceptual analysis and help answer our question on how we can make sense of organizational rules in the presence of monetary and nonmonetary 
motives. The regression analysis examines the linkages between motives, organizational processes and worker commitment in terms of willingness to exert additional effort. It was carried out by means of categorical principal component analysis (CatPCA), ordered logit and OLS models. Details about the survey and data set are reported in the Appendix.

A social cooperative pursues explicit societal aims by combining users and workers' interests. The nature of the services offered is often nonstandard, personalized and directed toward specific community needs involving interaction with and support to weak and vulnerable people (O'Donovan et al., 2013; Griffiths and Woods, 2009; Borzaga and Depedri, 2005). In Italy, as well as in some other continental European countries, socially oriented organizations, including cooperative forms, are required by law to include multiple stakeholders in their governance bodies, albeit empirical evidence for Italy indicates that membership remains strongly attached to workers (Borzaga et al., 2011; Tortia, 2020). These organizations also are characterized by the presence of a not-for-profit constraint and asset lock, whose function is to build resources that work to protect members and users against emerging risks, toward increasing stability and ensuring that outcomes contribute to the creation of societal benefit (Borzaga and Tortia, 2010).

The reasons for the prominence of prosocial motives in social cooperatives have been related to these organizations' nature, which is value-based and defined by their societal aims and the relational nature of work (Borzaga and Depedri, 2005; Gui and Sugden, 2005; Grant, 2007). In this context, workers' initial motives provide a measure of attitudes held by workers prior to entering the organization. Thus, we assume that motives are not conducive to the organization's specific characteristics [2]. In this sense, initial motives indicate the degree of congruence between worker motivations and organizational aims.

\subsection{Motives}

Table 1 shows workers' initial motives to join the organization. Descriptive statistics illustrate average values for each selected item. We observed the highest scores for collective, nonmonetary motives, including "helping people with difficulties" (5.5/7). The second and third items, in order of importance, refer to self-oriented motives and "to have the opportunity of professional achievement" (5.4/7) and a salary (4.9/7). The item "sharing the values of the co-operative organization" (4.7/7) scored higher than the "possibility to partake in decisionmaking" (4/7), indicating that the need to be part of a collective that embodies shared values and takes an interest in others' welfare is stronger than the need for actual involvement in organizational processes. This can be explained through social cooperatives' specific prosocial nature and the internal system of representation, whereby workers delegate decision-making to elected members as long as they are trusted and respect broadly shared values.

\subsection{Incentives}

We can pair observations about motives with incentives. Table 1 refers to the organization's utilization of different incentive tools, including monetary, contract-related and material (e.g. economic incentives, career, flexible working time, health, safety, etc.) and nonmonetary and value-laden (e.g. participation in the mission, professional growth and interpersonal relations). Descriptive statistics show that individual monetary-related motives complement collective nonmonetary motives (see also Leete, 2000). These are related primarily to these organizations partaking in an activity oriented toward the public good. Concurrently, nonmonetary motives related to actual participation in decision-making at the organizational level appear to be relatively less motivational at an initial stage.

Table 2 shows the type of incentives that the same social cooperatives used. The question items focused on the incentives that workers identified. A simple glance at the mean values
Governing cooperatives and individual motives 


\begin{tabular}{|c|c|c|c|c|c|c|c|}
\hline \multirow[b]{2}{*}{$\begin{array}{l}\text { IJSE } \\
48,2\end{array}$} & \\
\hline & & $\begin{array}{l}\text { To help } \\
\text { people with } \\
\text { difficulties }\end{array}$ & $\begin{array}{l}\text { Professional } \\
\text { self- } \\
\text { actualization }\end{array}$ & $\begin{array}{c}\text { Income and } \\
\text { occupational } \\
\text { needs }\end{array}$ & $\begin{array}{c}\text { Sharing } \\
\text { the same } \\
\text { values }\end{array}$ & $\begin{array}{l}\text { To satisfy } \\
\text { community } \\
\text { needs }\end{array}$ & $\begin{array}{c}\text { To } \\
\text { participate in } \\
\text { making } \\
\text { decisions }\end{array}$ \\
\hline \multirow{6}{*}{188} & Mean & 5.46 & 5.38 & 4.92 & 4.66 & 4.21 & 4.01 \\
\hline & Median & 6 & 6 & 5 & 5 & 4 & 4 \\
\hline & Mode & 7 & 6 & 7 & 6 & 4 & 4 \\
\hline & $\begin{array}{l}\text { Standard } \\
\text { Dev }\end{array}$ & 1.50 & 1.45 & 1.80 & 1.73 & 1.69 & 1.84 \\
\hline & $\begin{array}{l}\text { Var. coeff. } \\
\text { (mean/st. } \\
\text { dev.) }\end{array}$ & 0.27 & 0.27 & 0.37 & 0.37 & 0.40 & 0.46 \\
\hline & $\begin{array}{l}\text { Nr. cases } \\
\text { (out of } \\
4,134 \text { ) }\end{array}$ & 3,939 & 3,902 & 3,934 & 3,883 & 3,844 & 3,857 \\
\hline
\end{tabular}

Table 1.

Motives that have attracted workers to Italian social cooperatives
Note(s): Question: "To what extent each of the following reasons have attracted you to work in this cooperative?" (Likert 1-7). Selected items: 1 . The possibility to satisfy income and occupational needs. 2. To contribute to help people with difficulties. 3. To find an opportunity for professional self-actualization. 4. The possibility to satisfy community needs. 5 . Sharing the cooperative values. 6 . The possibility to participate in making decisions. See Appendix for tests

Source(s): Authors' elaboration on ICSI Survey. Respondents are workers (total cases 4,134)

indicates that incentives respond mainly to the nature of membership. Social cooperatives motivate workers by using soft incentives, that is, by reinforcing organizational features consistent with enhancing nonmonetary elements of members' welfare. In this case, considering that social cooperatives feature a prominent presence of workers in their membership, incentives match workers' needs, with an emphasis on job stability and other contractual elements. These incentives are expected to compensate in part for the level of monetary remuneration when this is lower than productivity (Borzaga and Depedri, 2005).

In support of incentives that target nonmonetary motives, Becchetti et al. (2013), using the same data set, show that workers' stronger intrinsic motivations are conducive to better work performance in terms of effort and productivity. In turn, strong nonmonetary motives also appear to be reflected in higher monetary remuneration (wages). A closer coupling of intrinsic motivations and higher wages does not imply that cooperatives bear higher costs than conventional firms because average wages usually are lower in the former (Pencavel et al., 2006; Borzaga and Tortia, 2010).

\subsection{Value congruence and risk of opportunism}

The data set also allows for observing management's view on the issue of value congruence between the organization and cooperators, which we present in Table 3. Managers were asked whether members share, partially or completely, the same values and principles of cooperation that drive the organization's social mission statement. Wherever value consistency is partial or weak, the accomplishment of cooperative behaviors can be at risk. We then considered the degree of mismatching as an indicator of the risk of opportunism. Percentages indicate that widespread consistency in values exists for about $57 \%$ of the organizations, while in $30 \%$ of cooperatives, members share only part of the organization's values. Still, the comparison between members and nonmembers indicates that being a member improves the level of value congruence, thereby possibly reducing the risk of opportunism within the organization.

\subsection{Rule congruence and commitment}

A nonsecondary consequence of the mismatch between individual motives and organizational rules may be the emergence of X-inefficiency, for example, when members 


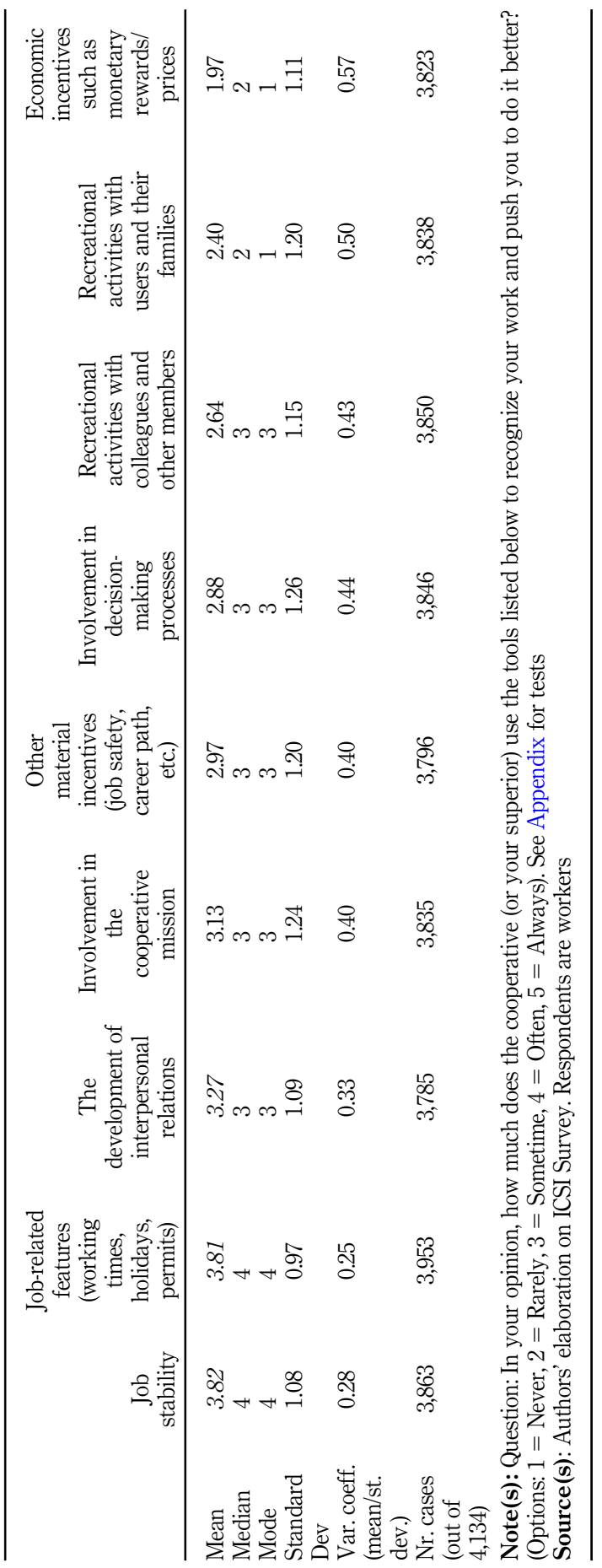

Governing cooperatives and individual motives

189

Table 2

Nonmonetary and monetary incentives 


\section{IJSE \\ 48,2}

\section{0}

Table 3.

Value consistency between the organization and its members and nonmember workers

\begin{tabular}{|c|c|c|c|c|}
\hline & $\begin{array}{c}\text { Among members } \\
\text { (Nr. of organizations) }\end{array}$ & $\%$ & $\begin{array}{l}\text { Among nonmember workers } \\
\text { (Nr. of organizations) }\end{array}$ & $\%$ \\
\hline Widespread sharing & 167 & 56.61 & 123 & 43.62 \\
\hline Only a part of them shares & 88 & 29.83 & 94 & 33.33 \\
\hline No real sharing & 5 & 1.69 & 17 & 6.03 \\
\hline $\begin{array}{l}\text { Different categories have } \\
\text { different values }\end{array}$ & 32 & 10.85 & 38 & 13.48 \\
\hline Don’t know & 3 & 1.02 & 10 & 3.55 \\
\hline Total & 295 & 100.00 & 282 & 100.00 \\
\hline
\end{tabular}

Note(s): Question: What is your opinion about the sharing of values (and of the mission) among members/ workers of the organization? All items: 1. among the members/workers there is a widespread sharing of values and principles; 2 . only a part of the members/workers shares values and principles; 3 . among the members/ workers there is no real sharing of values and principles; 4. different categories of members/workers have different values and principles; 5 . I do not know. See Appendix for tests

Source(s): Authors' elaboration on ICSI Survey. Respondents are managers

reduce their commitment or resist organizational strategies (Leibenstein, 1966). In this case, we can expect that effort also would be lower, while control and other organizational costs would rise. Orthodox approaches have prescribed several remedies, ranging from increasing hierarchy to tightening control and pay for performance (Lazear and Shaw, 2000). However, critics acknowledge that these cures may be liable to increase costs without guaranteeing expected efficiency (Frey and Osterloh, 2005; Akerlof and Kranton, 2005).

As a proxy for the stated desire to commit to different organizational aims, we use workers' stated willingness to increase effort levels should the organization be ready to implement different (monetary and nonmonetary) organizational processes and practices. Our data indicate that, in social cooperatives, workers relate commitment to both monetary and nonmonetary features, as well as job stability, but not so much to hierarchical control. Table 4 shows the conditions under which workers would increase their effort. Tightened control is one of the least important actions that the cooperative could take according to workers, while performance-related incentives and salary carry the greatest importance. This result reveals that, for future commitment decisions, monetary incentives become important over time, complementing immaterial incentives. Among immaterial features, work creativity and recognition from superiors would encourage workers to be more committed to their jobs. Overall, workers appear to consider performance-related incentives highly when deciding whether to increase effort. However, no one single feature stands out. Instead, workers seem to be willing to commit more effort depending on a variety of actions that the cooperative could take, in which recognition occurs not only in monetary terms, but also with respect to the nature of the job (creativity, autonomy), the nature of the organization (involvement) and the quality of relationships (fairness).

\subsection{Regression analysis}

In this section, we used cross-sectional survey data to test some aforementioned relationships. Specifically, we tested whether individual motives and (monetary and nonmonetary) incentives are related to workers' commitment in terms of willingness to exert increased effort, should the organization be ready to improve its organizational processes, particularly in terms of job stability, fair processes, distributive patterns, autonomy and creativity. Separate regressions were run when considering worker motives and organizational tools or incentives as regressors that influence commitment. A series of individual, organizational and contextual variables was added to control for disturbing effects. Given the data's cross- 


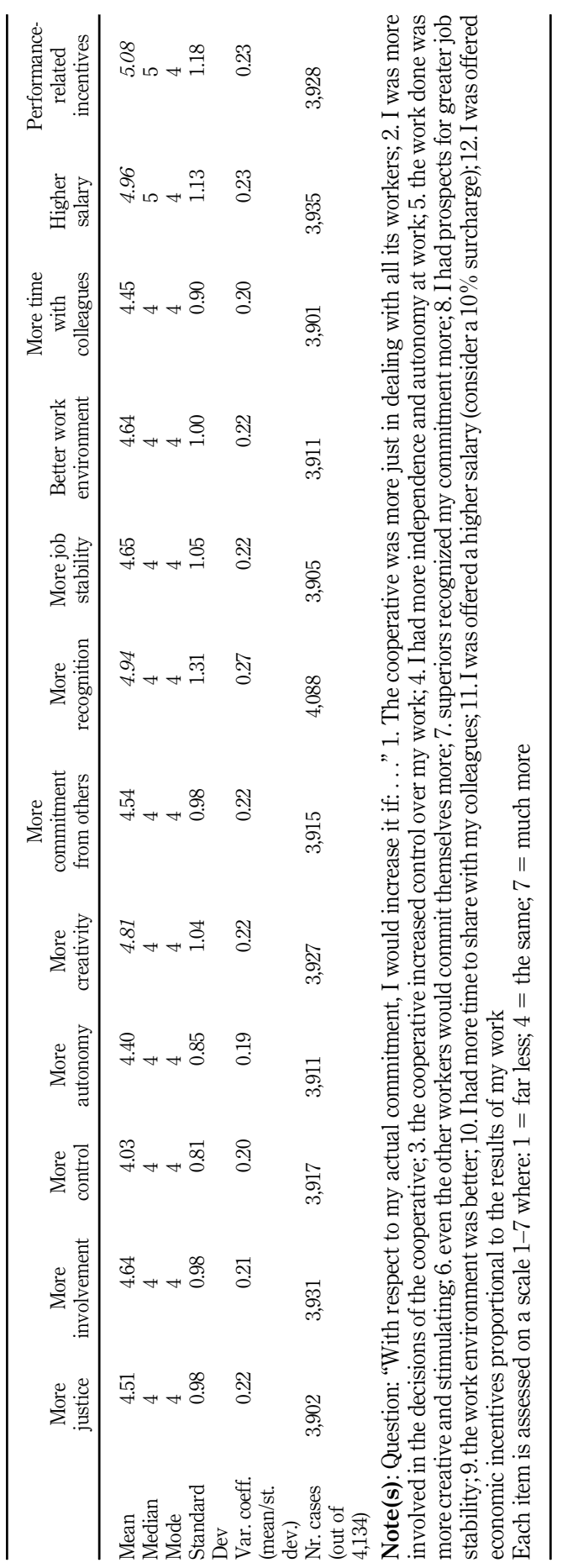

Governing cooperatives and individual motives 
IJSE

48,2

192

sectional nature, we did not make any causality claims, but rather sought to highlight some relevant statistical linkages derived from rich and detailed survey data. This kind of analysis can help clarify important theoretical arguments and lead to more robust tests in the future.

The dependent variables representing commitment were derived from a multi-item question in the original questionnaire (12 items overall). To reduce the high number of dimensions representing (nonmonetary) organizational processes (ten items), we ran a CatPCA to extract a smaller number of latent dimensions representing the whole commitment phenomenon [3]. Only one component with an eigenvalue higher than 1 and Cronbach's alpha higher than 0.7 (precisely, $\alpha=0.871$ ) was extracted (CatPCA output is in Appendix, Table A5). We used component scores from CatPCA as dependent variables in two different OLS regressions in which, aside from all the control variables, individual motives (Reg. A1) and organizational tools (Reg. A2) were added as regressors in the analysis. Items 11 and 12 concern monetary dimensions that are clearly different from the other nonmonetary ones. Given their ordinal nature, we estimated four order logit regression models at the mean value of the independent variables, in which wage level (Regs. B1 and B2) and the intensity of monetary incentives (Regs. C1 and C2) were used as dependent variables. Regressors were the same as in the models concerning nonmonetary dimensions (Table 5). The control variables including sociodemographic, organizational and contextual dimensions - were as follows: At the individual-worker level, whether the worker is a member of the co-op or a simple employee; age; gender; type of contract (e.g. open-ended vs short-term, part-time vs full-time); tenure in the co-op; hourly wage; and secondary school or university degree (two separate dummies for educational achievement). At the organizational level, we included firm type (Type A vs Type B social co-op) and log of size in terms of number of employed workers. As a contextual dimension, we included the log of provincial income (Italy has 107 provinces). In Table 5, we did not include econometric estimates for control variables, as only workers' age is statistically significant.

As concerns workers' motives (regs. A1, B1 and C1), the results show that worker commitment is best supported by the desire to fulfill income and occupational needs, as well as achieve professional self-actualization. Also, value dimensions that regard others play a crucial role, especially the desire to satisfy community needs and help people with difficulties. These motivational dimensions are factored in when workers find a positive relationship between their professional and other-regarding objectives and the policies that their organizations implement to satisfy such needs. On the other hand, sharing similar values does not generate improved commitment (i.e. workers are not willing to increase effort based solely on shared values). This result may signify that the abstract sharing of values already is taken for granted and that workers seek actual correspondence between their professional growth and values and organizational practices.

As for organizational tools that the organization uses on an ongoing basis, job features (working times, permits, etc.) and the development of interpersonal relationships appear to be particularly disconnected from workers' willingness to increase effort. Similar but weaker results were found in the case of involvement in decision-making and in the organization's mission. Furthermore, involvement in the mission and job-related features appear to be particularly important when commitment related to wage levels is considered, but again with a negative sign (odds ratio lower than 1 in regression B2). Clearly, improved job features and better interpersonal relationships and involvement do not induce workers to increase work effort. This is probably due to workers perceiving that they already are exerting optimal effort in relation to these dimensions. Active organizational interventions would not improve this situation. Among control variables, only workers' age is (highly) statistically significant with a negative sign in all models, that is, over time, workers become more and more unresponsive to active organizational intervention. 


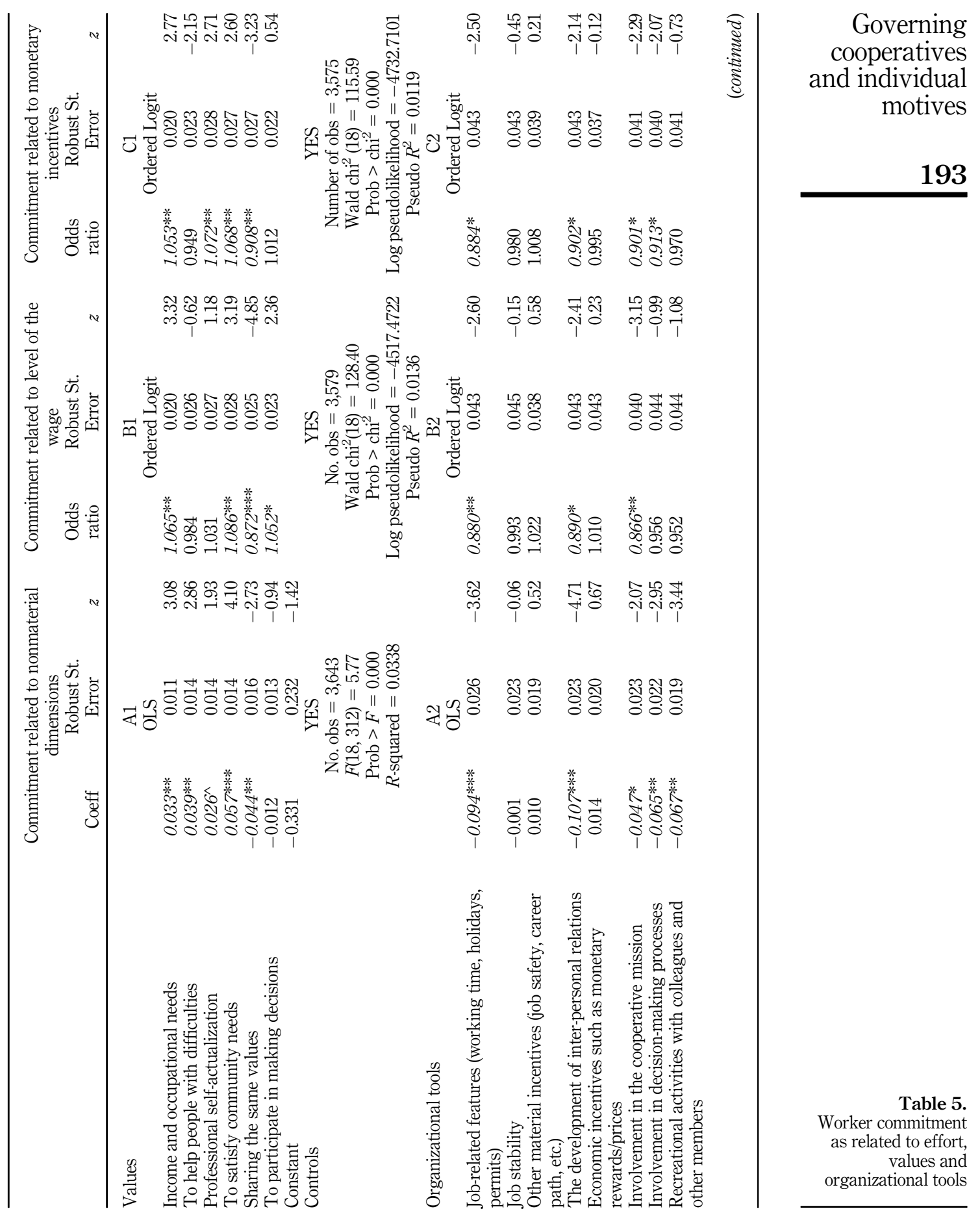




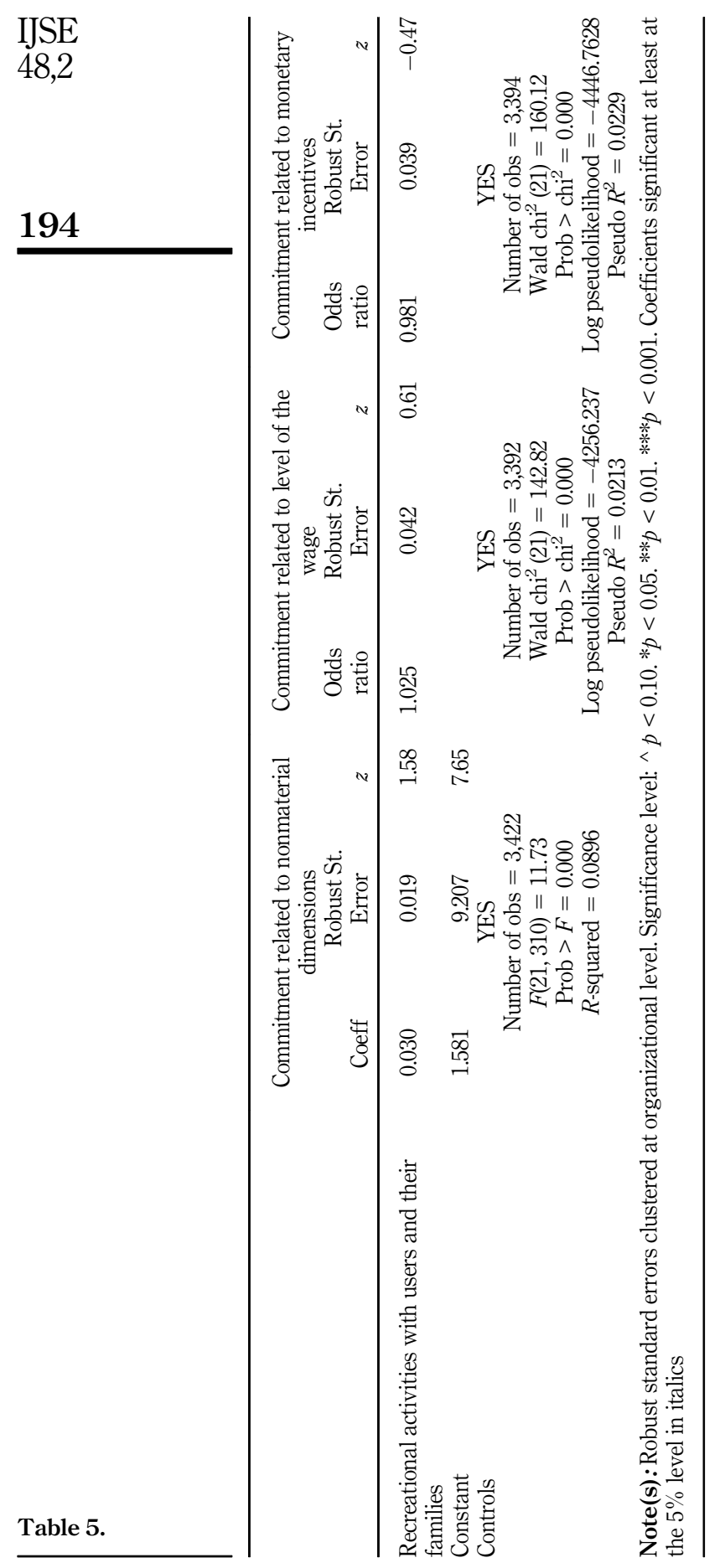




\section{Discussion of results: the individual-collective spheres framework}

Clearly, our illustration is limited to one specific type of cooperative, in which the presence of prosocial motives is expected to be wider and stronger than in other cooperative forms, although we can say that generally, the cooperative model emphasizes procommunity and prosocial aims.

Within a cooperative endeavor, as mentioned, the organization's identity is defined by specific values reflected by the rules autonomously defined by cooperators, along with their individual motives. To the extent that this circle of consistency is not broken, there would be no need to discuss cooperative failures. However, failures in practice and partial consistency elicit the need to highlight each element's role in reducing the risk of failure (Heath, 2009; Rawls, 1999). To test the coherent interaction between motives, rules, personal rights and commitment, we built a simple framework that includes the individual sphere of motives and the collective dimension defined by the spheres of rights at the societal level and the means and ends at the organizational level.

The problem with the choice of rules is framed in terms of a set of identified individual motives that are consistent with a corresponding set of ends. Motives and ends are connected by consistent sets of rules and rights. Firms choose a proper combination of ends and rules/ rights given individual motives, which are, in turn, linked to the firm's mission statement. We submit that consistency between collective and individual spheres requires that individuals' values be reflected by the definition of the organization's end objectives (Sen, 2002). Likewise, rights and organizational rules are the means that support the pursuit of desired ends. The implementation of rights and rules and the results from organized action then can be expected to tend toward realization of initial ends, as partial achievement and failure are possibilities. Over time, interaction with actual behaviors and environmental factors may change the value that decision-makers place on initial ends and means (Dewey, 1977). In this sense, experience, or the critical assessment of the efficiency and efficacy of particular sets of rights and rules, can be argued to represent the pragmatic element underpinning the adjustment and tuning of motives, rules and underlying rights (Williamson, 2000; Heath, 2009; Ostrom, 2010).

Generally, the framework implies that, in an economy, the broader the spectrum of motives recognized at fundamental institutional levels, the greater the capability of individuals to express themselves through specific organizational rules and the greater the match between rules and individual motives. With greater articulation of institutions through the definition of multiple rights - we would expect increases in the individual capability to match motives with specific organizational rules in pursuit of consistent ends. Thus, property rights are the foundational institutions of investor-owned organizations and are associated with investors' strategic control of resources for monetary gain. On the other hand, personal control rights are the foundational institutions of cooperative organizations and define the right to be included in the strategic control of the organization to create cooperators' benefit (which, as a norm, does not coincide with maximization of monetary gain). Also, the greater the match between organizational rules and individual motives, the lower the risk of opportunism, the stronger workers' commitment and the greater the expected efficacy of the organization in reaching desired ends (Bartlett et al., 1992).

The basic components of the framework are illustrated in Table 6, as well as their application to cooperative organizations. When cooperators join in a cooperative venture in pursuit of a common end, they transform personal control rights for self-determination into factual opportunities by giving themselves appropriate rules. Defining, monitoring and enforcing rules are all self-organized through constant interaction and learning to ensure, in the long run, the highest congruence between what the individual and what the organization and its stakeholders value at the collective level (Ostrom, 1990; Gandz and Bird, 1996; Perkins and Zimmerman, 1995; Hannachi et al., 2020).
Governing cooperatives and individual motives 
IJSE

48,2

196

Given cooperators' motives, rules that inhibit inclusion and participation may be perceived as unfair, exogenously defined or opposed to the organization's core values. In this context, self-given rules are not meant to limit the cooperator's personal rights, but rather to ensure that her/his right to be included in decisions, participate in the activity and share economic results is respected. Cooperators' efficacy to move toward desired ends goes beyond incentivizing monetary motives or sanctioning opportunism and embraces individuals' will to self-determine, learn and contribute with their own experience and knowledge to deal with relevant organizational issues (Deci and Ryan, 2000; Dewey, 1977).

Rather than constraining, rules can be viewed as a means to enable formal personal control rights - including incentives, monitoring and sanctioning as part of this enabling function - rather than as mere administrative control (cf. Commons, 1931, 1950). Considering that cooperation can be unstable when challenged by opportunism, monitoring and sanctions are used to strengthen the enabling function to preserve the collective basis for cooperation. At this point, Ostrom et al.'s (1993) experiment emphasizes that cooperators are concerned with fairness and, based on experience and relationships matured over time, can decide to make use of suboptimal rules, which do not match the application of sanctions with a strict economic rationale. Thus, the role of rules is to enhance cooperation by creating expected patterns of fair behavior (Ouchi, 1980). There is, in fact, consensus in the literature over the fact that if individuals expect cooperation from others, they most likely will cooperate, and that this type of expectation is intense among individuals who belong to the same group or to the same organization, thanks to personal knowledge, interaction and trust (Kogut and Zander, 1996). These conclusions are reinforced by cooperative firms' specificity.

\subsection{Evolution of rules}

When we argue for the need to match individual motives with organizational rules, we inevitably acknowledge an evolving equilibrium between what individuals assess as valuable and what is recognized as such by the organization. Clearly, motives can change subject to the individual's experience interacting with the organizational context and the external environment. Similarly, rules are understood as evolving entities that are contextualized historically and tested by experience and learning (Dewey, 1977). One way to create consistency between cooperative motives and organizational rules is to enact adjustment and change processes to reflect members' evolving, shared motivations. For example, from our illustration, we learned that while workers initially seem to be motivated mostly by prosocial and professionalization aims, their commitment decisions over time attributed increased importance to wage and monetary rewards that organizational policies should not disregard. Indeed, regression analysis confirmed that the importance given to income and occupational needs can influence commitment as much as community needs, while sharing values and involvement in decision-making and the organization's mission are not related to increased worker effort.

Table 6.

The individualcollective spheres framework applied to cooperative organizations

\begin{tabular}{lll}
\hline Spheres & Components & Features of cooperative organizations \\
\hline $\begin{array}{l}\text { 1. Individual } \\
\text { sphere }\end{array}$ & a. Motives & Multiple: monetary and nonmonetary; individual and collective \\
$\begin{array}{l}\text { 2. Sphere of rights } \\
\text { 3. Sphere of } \\
\text { means }\end{array}$ & $\begin{array}{l}\text { b. Institutions } \\
\text { c. Rules and } \\
\text { incentives } \\
\text { d. Decision-making }\end{array}$ & $\begin{array}{l}\text { Personal control rights } \\
\text { Self-defined, monetary and nonmonetary }\end{array}$ \\
$\begin{array}{l}\text { Democratic representation; participation, communication and } \\
\text { mutual learning } \\
\text { Cooperators' welfare }\end{array}$ \\
& $\begin{array}{l}\text { e. Organization's } \\
\text { aims }\end{array}$ & Cof end
\end{tabular}


The continuous scrutiny and adaptation of motives and means imply that cooperators communicate and engage in a learning process. The rules by which individuals communicate are learned experientially and can vary depending on the values driving the organization (Kreps, 1990). Therefore, in cooperatives, communication is supposed to occur through participation in a community that practices cooperation, according to rules that are expected to incentivize and stimulate that same process (cf. Lave and Wenger (1991) on the notion of "situated learning"). This provides a context in which individuals learn and contribute to the creation of a common discourse, including around the features of rules and their desirability. The motivation to cooperate then is reinforced by the fact that rules are the output from a shared learning process. Lakoff (1987) notices that individuals are motivated by what they understand, and understanding is high where individuals share the same cognitive categories and actively participate in organizational processes through horizontal interaction. These categories, in a cooperative, are provided by the values of cooperation.

The communication process motivates cooperators to improve awareness and understanding and to seek consensus (also in the presence of divergent motives) (Dewey, 1977; Habermas, 1996). It is a radically different interpretation of administrative coordination than what can be found in economic organization theory, which focuses on the use of authority to control actions and outcomes. A perspective on communication also leads to interpreting incentives and monitoring them very differently than in organizational economics. As Kogut and Zander (1996) emphasize, rather than being a way through which a principal assesses the agent's performance with respect to exogenously defined objectives, within cooperation monitoring is an opportunity for further discovery, learning and understanding, and in the case of cooperatives, for sustaining nonmonetary motives and moving toward shared aims. In this sense, according to Sabel (1994), rules and incentives serve the purpose of conveying previous experience and learning, thereby providing guidance to action. Moreover, using the transaction-costs argument, we can advance the hypothesis that communicative processes of this type reduce costs due to short-term interests, slack and opportunism. Consistently, control costs have been shown to be lower in cooperatives than in conventional corporations (Bartlett et al., 1992; Hansmann, 1996).

\section{Conclusions and recommendations}

While the institutional spheres that support investor-owned organizations and self-interested profit-maximizing behavior have been analyzed (cf. Williamson, 1973, 2000; Gibbons, 1998; Jensen and Mackling, 1976) and critically considered (cf. Blair, 1995), a framework that accommodates personal control rights and a richer view of individual motives is lacking.

The paper has suggested a possible framework through which to explain unconventional organizational forms such as cooperatives, their governance strengths and failures. In considering cooperative firms as entrepreneurial associations driven by participatory governance, in which cooperators are granted personal democratic and nonsaleable control rights, we have presented data on social cooperatives in Italy. The proposed framework emphasizes the links between multiple individual motives and organizational rules, suggesting that personal-control rights and consistent rules should be designed through adequate communication processes to define necessary constraints and facilitate the definition and enactment of self-defined aims and means, rather than controlling progress over exogenously defined ends. The framework then offers a broad guideline and diagnostic tool with which to assess cooperators' self-given rules and their potential to achieve desired ends, enabling the adaptation of rules to experience and evolving motives by means of communicative practices.

Our illustration evidences that initially, cooperators are driven strongly by nonmonetary motives and that incentives consistently place greater emphasis on nonmaterial returns than on monetary rewards. However, the congruence of individual motives and cooperative values
Governing cooperatives and individual motives 
IJSE

48,2

198

indicates a variety of shades and can be viewed as only partial. Also, it would be a mistake to rule out the role of monetary recognition and professional growth, which cooperators perceive as a source of greater effort. More specifically, nonmonetary incentives may reward cooperators better at initial stages, but then they should be balanced adequately with monetary rewards and professional growth.

This study's final recommendation is that to reduce cooperative governance failures, rules that regulate decision-making, incentives, monitoring and sanctioning need to match evolving motives, values and aims. Communication processes that involve mutual learning are central to tuning motives and rules, as well as ensuring the necessary commitment for progress toward desired ends. The overall arguments used to describe cooperative enterprises' unique features are meant to contribute to the debate on welfare effects from nontraditional organizational and governance forms. In-depth discussion of cooperative governance can shape opinions, influence models and inform practices that managers use. In the end, managerial models that explicitly factor in motives and cooperative values, and that also can control the spread of opportunism and incentivize effort, can affect quality of life positively. Social policies and regulations can recognize this potential and intervene to favor the spread of new and consistent practices and models.

\section{Notes}

1. Various authors view mutuality as being directly linked to involved actors' reciprocating behavior (Bruni and Zamagni 2007).

2. From the original questionnaire, we selected six of the original 14 Likert items (measured on a 1-7 scale) that define initial motivations' intensity. The items reported on workers' self-assessment at the time of the survey and, therefore, were retrieved through memory.

3. CatPCA is an optimal scaling technique that can be used to quantify ordinal categories and obtain numerical representations of each single item and component scores (Michailidis and de Leeuw, 1998; Meulman et al., 2004). Varimax rotation with Kaiser normalization was performed. Item No. 3 in the questionnaire, control over the operation of workers, was excluded, as it was the only one weighted in a second component with an eigenvalue lower than 1 (Table A5).

\section{References}

Akerlof, G.A. and Kranton, R. (2005), "Identity and the economics of organizations", Journal of Economic Perspectives, Vol. 19 No. 1, pp. 9-32.

Akinsoyinu, C.A. (2017), "Cooperative banks: is demutualization an answer? The experience of building Societies in the UK", in Miklaszewska, E. (Ed.), In Institutional Diversity in Banking, Palgrave Macmillan, pp. 73-100.

Bager, T. (1994), "Isomorphic processes and the transformation of cooperatives", Annals of Public and Cooperative Economics, Vol. 65 No. 1, pp. 35-59.

Bartlett, W., Cable, J., Estrin, S., Jones, D.C. and Smith, S.C. (1992), "Labor-managed Co-operatives and private firms in North-Central Italy: an empirical comparison", Industrial and Labor Relations Review, Vol. 46 No. 1, pp. 103-118.

Battilani, P. and Schröter, H.G. (2011), "Demutualization and its problems”, DSE Working Paper nr. 762, University of Bologna, Italy.

Becchetti, L., Castriota, S. and Tortia, E.C. (2013), "Productivity, wages and intrinsic motivations", Small Business Economics, Vol. 41 No. 2, pp. 379-399.

Blair, M.M. (1995), “Corporate 'ownership': a misleading word muddies the corporate governance debate", The Brookings Review, Vol. 13, pp. 16-19. 
Bonin, J.P., Jones, D.C. and Putterman, L. (1993), "Theoretical and empirical studies of producer cooperatives: will ever the twain meet?", Journal of Economic Literature, Vol. 31 No. 3, pp. $1290-1320$.

Borzaga, C. and Depedri, S. (2005), "Interpersonal relations and job satisfaction: some empirical results in social and community care services", in Gui, B. and Sugden, R. (Eds), Economics and Social Interaction: Accounting for Interpersonal Relations, Cambridge University Press, Cambridge, pp. 132-153.

Borzaga, C. and Tortia, E.C. (2010), "The economics of social enterprises.", in Becchetti, L. and Borzaga, C. (Eds), The Economics of Social Responsibility. The World of Social Enterprises, Routledge, London and New York, pp. 15-33.

Borzaga, C., Depdri, S. and Tortia, E.C. (2011), "Organisational variety in market economies and the role of Co-operative and social enterprises: a plea for economic pluralism", Journal of Cooperative Studies, Vol. 44 No. 1, p. 19.

Brummer, V., Herbes, C. and Gericke, N. (2017), "Conflict handling in renewable energy cooperatives (RECs): organizational effects and member well-being", Annals of Public and Cooperative Economics, Vol. 88 No. 2, pp. 179-202.

Bruni, L. and Zamagni, S. (2007), Civil Economy, Efficiency, Equity, Public Happiness, Peter Lang, Oxford.

Chaddad, F. and Cook, M. (2004), "Understanding new cooperative models: an ownership-control rights typology", Review of Agricultural Economics, Vol. 26 No. 3, pp. 348-360, doi: 10.1111/j. 1467-9353.2004.00184.x.

Commons, J.R. (1931), "Institutional economics", American Economic Review, Vol. 21 No. 4, pp. 648-657.

Commons, J.R. (1950), The Economics of Collective Action, Macmillan, New York, NY.

Connell, D.J. (1999), “Collective entrepreneurship”, in Search of Meaning, Online, University of Brish Columbia, available at: https:/www.unbc.ca/sites/default/files/sections/david-connell/ connell1999collectiveentrepreneurship_0.pdf (accessed 24 December 2020).

Cook, J., Deakin, S. and Hughes, A. (2015), "Mutuality and corporate governance: the evolution of UK building Societies following deregulation", Journal of Corporate Law Studies, Vol. 2 No. 1, pp. 110-138.

Cornforth, C. (2004), "The governance of Co-operatives and mutual associations: a paradox perspective", Annals of Public and Cooperative Economics, Vol. 75 No. 1, pp. 11-32.

Dawes, R.M. and Thaler, R.H. (1988), “Anomalies: cooperation”, Journal of Economic Perspectives, Vol. 2 No. 3, pp. 187-197.

Deci, E.L. and Ryan, R.M. (2000), "Self-determination theory and the facilitation of intrinsic motivation, social development and well-being", American Psychologist, Vol. 55, pp. 68-78.

Dewey, J. (1977), "Creative intelligence: essays in the pragmatic attitude", in Sidorsky, D. (Ed.), John Dewey, Harper, New York, NY, pp. 70-95.

Ellerman, D. (2017), "Worker Co-operatives as based on first principles", Journal of Entrepreneurial and Organizational Diversity, Vol. 5 No. 1, pp. 20-32.

Frey, B.S. and Osterloh, M. (2005), "Yes, managers should be paid like bureaucrats", Journal of Management Inquiry, Vol. 14 No. 1, pp. 96-111.

Fulton, M. and Hueth, B. (2009), "Cooperative conversions, failures and restructurings. An overview”, Journal of Cooperatives, Vol. 23, pp. 1-11.

Furubotn, E.G. and Pejovich, S. (1970), "Property rights and the behaviour of the firm in a socialist state: the example of Yugoslavia", Zeitschrift für Nationalokonomie, Vol. 30 No. 5, pp. 431-454.

Gandz, J. and Bird, F.G. (1996), "The Ethics of empowerment”, Journal of Business Ethics, Vol. 15 No. 4, pp. 383-392. 
IJSE

48,2

Gibbons, R. (1998), "Incentives in organizations", Journal of Economic Perspectives, Vol. 12, pp. $115-132$.

Grant, A.M. (2007), "Relational job design and the motivation to make a pro-social difference in other people's lives", Academy of Management Review, Vol. 32 No. 2, pp. 393-417.

Griffiths, M. and Woods, L. (2009), Vulnerability Analysis: The Building Blocks for Successful Livelihood Intervention, UNOPS, Yangon.

Gui, B. and Sugden, R. (Eds), (2005), in Economics and Social Interaction: Accounting for Interpersonal Relations, Cambridge University Press, Cambridge.

Habermas, J. (1996), Between Facts and Norms: Contributions to a Discourse Theory of Law and Democracy, MIT Press, Cambridge, MA.

Hannachi, M., Faresb, M., Colenoa, F. and Assens, C. (2020), “The 'new agricultural collectivism': how cooperatives horizontal coordination drive multi-stakeholders self-organization", Journal of Cooperative Organization and Management, Vol. 8 No. 2, doi: 10.1016/j.jcom.2020.100111.

Hansmann, H.B. (1988), "Ownership of the firm”, Journal of Law, Economics, and Organization, Vol. 4 No. 2, pp. 267-304.

Hansmann, H.B. (1996), The Ownership of Enterprise, The Belknap Press of Harvard University Press, Cambridge, MA.

Heath, J. (2009), "The uses and abuses of agency theory", Business Ethics Quarterly, Vol. 19 No. 4, pp. 497-528.

Hernandez, S. (2006), "Striving for control: democracy and oligarchy at a Mexican Co-operative", Economic and Industrial Democracy, Vol. 27 No. 1, pp. 105-135.

Hoffmann, E.A. (2005), "Dispute resolution in a worker cooperative: formal procedures and procedural justice", Law and Society Review, Vol. 39, pp. 51-82.

Iliopoulos, C. and Valentinov, V. (2017), "Member preference heterogeneity and system-lifeworld dichotomy in cooperatives", Journal of Organizational Change Management, Vol. 30 No. 7, pp. 1063-1080.

Jensen, M.C. and Meckling, W.J. (1976), "Theory of the firm: managerial behavior, agency costs and ownership structure", Journal of Financial Economics, Vol. 3, pp. 305-360.

Kogut, B. and Zander, U. (1996), "What firms do? Coordination, identity, and learning”, Organization Science, Vol. 7 No. 5, pp. 502-518.

Kreps, D.M. (1990), "Corporate culture and economic theory", in Alt, J.E. and Shepsle, K.A. (Eds), Perspectives on Positive Political Economy, Cambridge University Press, Cambridge, pp. 90-143.

Lakoff, G. (1987), "Women, fire, and dangerous things", in What Categories Reveal about the Mind, University of Chicago Press, Chicago.

Lave, J. and Wenger, E. (1991), Situated Learning, Cambridge University Press, Cambridge.

Lazear, E.P. and Shaw, K.L. (2000), "Performance pay and productivity", American Economic Review, Vol. 90 No. 5, pp. 1346-1361.

Leete, L. (2000), "Wage equity and employment motivation in Nonprofit and for-profit organizations", Journal of Economic Behavior and Organization, Vol. 43 No. 4, pp. 423-446.

Leibenstein, H. (1966), "Allocative efficiency vs. 'X-efficiency", The American Economic Review, Vol. 56 No. 3, pp. 392-415.

MacPherson, I. (2013), “cooperative's concern for the community: from members towards local communities' interest”, Euricse Working Paper n. 46, European Research Institute on Cooperative and Social Enterprise, Trento.

Maitland, I., Bryson, J. and van de Ven, A. (1985), “£Sociologists, economists, and opportunism”, The Academy of Management Review, Vol. 10 No. 1, pp. 59-65. 
Meulman, J., Van der Kooi, A.J. and Heiser, W.J. (2004), "Principal component analysis with nonlinear optimal scaling transformations for ordinal and nominal data", in Kaplan, D. (Ed.), The Sage Handbook of Quantitative Methodology for the Social Sciences, Sage, London, pp. 49-70.

Michailidis, G. and de Leeuw, J. (1998), "The Gifi system of descriptive multivariate analysis", Statistical Science, Vol. 13 No. 4, pp. 307-336.

Milgrom, P. and Roberts, J. (1992), Economics, Organization and Management, Prentice Hall, Upper Saddle River, NJ.

Mojtahed, D. (2007), "Conflict management of cooperative organizations in contemporary Iran: a review analysis", Public Organization Review, Vol. 7, pp. 163-180.

Nilsson, J., Kihlén, A. and Norell, L. (2009), "Are traditional cooperatives an endangered species? About shrinking satisfaction, involvement and trust", International Food and Agribusiness Management Review, Vol. 12 No. 4, pp. 101-122.

Nilsson, J. (2018), "Governance costs and the problems of large traditional Co-operatives", Outlook on Agriculture, Vol. 47 No. 2, pp. 87-92.

Nuhanovic-Ribic, S. (2015), "The political economy of agricultural cooperatives in Bosnia and Herzegovina: towards a sustainable rural development model”, Doctoral dissertation, Department of Economics and Management, University of Trento.

O' Donovan, R., Doody, O. and Lyons, R. (2013), "The effect of stress on health and its implications for nursing", British Journal of Nursing, Vol. 22 No. 1, pp. 969-973.

Ostrom, E. (1990), Governing the Commons. The Evolution of Institutions for Collective Action, Cambridge University Press, Cambridge, MA.

Ostrom, E. (2010), "Beyond markets and states: polycentric governance of complex economic systems", American Economie Review, Vol. 100 No. 3, pp. 641-672, doi: 10.1257/aer. 100.3.641.

Ostrom, E., Schroeder, L. and Wynne, S. (1993), Institutional Incentives and Sustainable Development: Infrastructure Policies in Perspective, Westview, Boulder, CO.

Ouchi, W.G. (1980), "Markets, bureaucracies and clans", Administrative Science Quarterly, Vol. 25 No. 1, pp. 129-142.

Pencavel, J., Pistaferri, L. and Schivardi, F. (2006), "Wages, employment, and capital in capitalist and worker-owned firms", Industrial and Labor Relations Review, Vol. 60 No. 1, pp. 23-44.

Perkins, D.D. and Zimmerman, M.A. (1995), "Empowerment theory, research and application", American Journal of Community Psychology, Vol. 23 No. 5, pp. 569-579.

Putterman, L. (1988), "The firm as association versus the firm as commodity: efficiency, rights, and ownership", Economics and Philosophy, Vol. 4 No. 2, pp. 243-266.

Rawls, J. (1999), A Theory of Justice, 2nd ed., Harvard University Press, Cambridge (MA).

Reich, R.B. (1987), "Entrepreneurship reconsidered: the team as a hero", Harvard Business Review, Vol. 65 No. 3, pp. 22-83.

Sabel, C. (1994), "Learning by monitoring: the institutions of economic development", in Smelser, N. and Swedberg, R. (Eds), Handbook of Economic Sociology, Princeton University Press, Princeton, NJ.

Sacchetti, S. and Borzaga, C. (2020), "The Foundations of the "Public Organisation": governance failure and the problem of external effects", Journal of Management and Governance. doi: 10. 1007/s10997-020-09525-x.

Sacchetti, S. and Tortia, E.C. (2016), "The extended governance of cooperative firms: inter-firm coordination and consistency of values", Annals of Public and Cooperative Economics, Vol. 87 No. 1, pp. 93-116.

Sen, A. (2002), Rationality and Freedom, Harvard University Press, Cambridge, MA.

Shiwakoti, R.K., Iqbal, A. and Funnell, W. (2018), "Organizational form, business strategies and the demise of demutualized building Societies in the UK", Journal of Banking and Finance, Vol. 94, pp. 337-350. 
IJSE

48,2

Spear, R. (2004), "Governance in democratic member-based organizations", Annals of Public and Cooperative Economics, Vol. 75 No. 1, pp. 33-60.

Spear, R. (2012), "Innovation and collective entrepreneurship", International Journal on Human Development and International Co-operation, Vol. 3 No. 2, pp. 1-15, available at: http://oro.open. ac.uk/2536/1/123-807-1-PB.pdf (accessed 17 October 2016).

Staatz, J.M. (1987), "The structural characteristics of farmer cooperatives and their behavioral consequences", in Royer, J.S. (Ed.), Cooperative Theory: New Approaches, U.S. Dept. of Agriculture, Agricultural Cooperative Service, Washington, DC, Vol. 18, pp. 33-60.

Stewart, A. (1989), Team Entrepreneurship, Sage, Newbury Park, CA.

Tortia, E.C., Sacchetti, S. and Valentinov, V. (2020), "The 'protective function' of social enterprises: understanding the renewal of multiple sets of motivations", Review of Social Economy, Vol. 78 No. 2, pp. 1-31.

Tortia, E.C. (2020), "From non-profit organizations, to multi-stakeholder social enterprises", Online, Online conference: Corporate Governance: Examining Key Challenges and Perspectives (Lisbon), available at: https://www.virtusgccg.org/-international-conference-in-lisbon-may-7-2020-html (accessed 23 September 2020).

Travaglini, C. (2012), "The generation and Re-generation of social capital and enterprises in multistakeholders social cooperative enterprises: a system dynamic approach", Revista de Administracao, Vol. 47 No. 3, pp. 436-445.

Valentinov, V. (2008), "Toward an incentive alignment theory of Nonprofit organization”, Evolutionary and Institutional Economics Review, Vol. 5 No. 1, pp. 189-196.

Vanek, J. (1970), The General Theory of Labour Managed Market Economies, Cornell University Press, Ithaca, NY.

Vanek, J. (1977), The Labor-Managed Economy: Essays by Jaroslav Vanek, Cornell University Press, Ithaca, NY.

Varman, R. and Chakrabarti, M. (2004), "Contradictions of democracy in a workers' cooperative", Organization Studies, Vol. 25 No. 2, pp. 183-208.

Vieta, M., Tarhan, M.D. and Duguid, F. (2016), "from collective to co-operative entrepreneurship in Canada's new co-operatives", Ontario Institute for Studies in Education, University of Toronto, available at: http://ccr.ica.coop/sites/ccr.ica.coop/files/attachments/2.2\%20Vieta_Tarhan_ Duguid.pdf (accessed October 2016).

Von Pischke, J.D. and Rouse, J.G. (2004), New Strategies for Mobilizing Capital in Agricultural Cooperatives, Rural Development Division, FAO, Rome, available at: http://www.fao.org/docrep/ 007/y5469e/y5469e00.htm (accessed October 2016).

Ward, B. (1958), "The firm in Illyria, market syndicalism", The American Economic Review, Vol. 48 No. 4, pp. 566-589.

Williamson, O.E. (1973), "Markets and hierarchies: some elementary considerations", American Economic Review, Vol. 63 No. 2, pp. 316-325.

Williamson, O.E. (1975), Markets and Hierarchies, Free Press, New York, NY.

Williamson, O.E. (2000), “The new institutional economics. Taking stock, looking ahead”, Journal of Economic Literature, Vol. 38 No. 1, pp. 595-613.

Yan, J. and Yan, L. (2016), "Individual entrepreneurship, collective entrepreneurship and innovation in small business: an empirical study", International Entrepreneurship and Management Journal, Vol. 12 No. 4, pp. 1053-1077.

\section{Further reading}

Bendix, R. (1956), Work and Authority in Industry: Ideologies of Management in the Course of Industrialization, University of California Press, Berkeley. 
Birchall, J. (2013), Resilience in a Downturn: The Power of Financial Cooperatives, Online, ILO 2013, Geneva, available at: http://www.ilo.org/wcmsp5/groups/public/—ed_emp/—emp_ent/—coop/ documents/publication/wcms_207768.pdf (accessed 1st July 2017).

Cowling, K. and Sugden, R. (1998), "The essence of the modern corporation: markets, strategic decision-making and the theory of the firm", The Manchester School, Vol. 66 No. 1, pp. 59-86.

Donaldson, T. (1982), Corporations and Morality, Prentice Hall, Englewood Cliffs NJ.

Gagnè, M. and Deci, E.L. (2005), "Self-determination theory and work motivation", Journal of Organizational Behavior, Vol. 26, pp. 331-362.

Hymer, S. (1972), "The internationalization of capital", Journal of Economic Issues, Vol. 6 No. 1, pp. 91-111.

Kogut, B. and Zander, U. (1992), "Knowledge of the firm, combinative capabilities, and the replication of technology", Organization Science, Vol. 3 No. 3, pp. 383-397.

Maslow, A.H. (1998), Maslow on Management, Wiley, New York, NY, Originally published as Eupsychian Management: A Journal. Homewood, IL: Irwin-Dorsey 1965.

Rose-Ackerman, S. (1996), "Altruism, nonprofits, and economic theory", Journal of Economic Literature, Vol. 34 No. 2, pp. 701-728.

\section{Appendix}

The Appendix files are available online for this article.

\section{About the authors}

Silvia Sacchetti has a PhD from the University of Birmingham (UK). She is currently associate professor at the Department of Sociology and Social Research at the University of Trento (Italy) and collaborates with Euricse. Her research interests are in the inclusive development of economies, which she studies from the point of view of third sector organizations and inclusive governance structures. She focuses on cooperative firms and social enterprises, recently studied in the context of welfare services. Her research has addressed also the role of creativity, social capital and individual motivations in enterprise and local development. Silvia's most recent publications have appeared in Journal of Business Ethics, Annals of Public and Cooperative Economics, Journal of Entrepreneurial and Organizational Diversity. Silvia is cochief editor of the Journal of Entrepreneurial and Organizational Diversity and Board member of the European Management Journal. She is a member of the European Research Board of the International Cooperative Alliance. Silvia Sacchetti is the corresponding author and can be contacted at: silvia.sacchetti@unitn.it

Ermanno Celeste Tortia is associate professor at the University of Trento. His research focuses on the theory of the firm, business economics, personnel economics and human resource management, as applied to third sector research and the organizational forms in the social economy (cooperative and social enterprises, nonprofit organizations). He has authored several empirical studies dealing with happiness economics, on-the-job satisfaction, organizational justice and worker motivations. He has also authored several studies in the institutionalist theory of social economy organizations. He collaborates closely with Euricse (European Research Institute on Cooperative and Social Enterprises, Trento, Italy); is member of the scientific committee of JEOD, Journal of Entrepreneurial and Organizational Diversity and teaching member of the PhD Program in Development Economics and Local Systems (DELoS), University of Florence.

For instructions on how to order reprints of this article, please visit our website:

www.emeraldgrouppublishing.com/licensing/reprints.htm

Or contact us for further details: permissions@emeraldinsight.com 